\title{
Animal transgenesis: state of the art and applications
}

\author{
Eduardo O. Melo, Aurea M.O. Canavessi, Mauricio M. Franco, Rodolfo Rumpf
}

EMBRAPA Genetic Resources and Biotechnology, Brasilia, DF, Brazil

\begin{abstract}
There is a constant expectation for fast improvement of livestock production and human health care products. The advent of DNA recombinant technology and the possibility of gene transfer between organisms of distinct species, or even distinct phylogenic kingdoms, has opened a wide range of possibilities. Nowadays we can produce human insulin in bacteria or human coagulation factors in cattle milk. The recent advances in gene transfer, animal cloning, and assisted reproductive techniques have partly fulfilled the expectation in the field of livestock transgenesis. This paper reviews the recent advances and applications of transgenesis in livestock and their derivative products. At first, the state of art and the techniques that enhance the efficiency of livestock transgenesis are presented. The consequent reduction in the cost and time necessary to reach a final product has enabled the multiplication of transgenic prototypes around the world. We also analyze here some emerging applications of livestock transgenesis in the field of pharmacology, meat and dairy industry, xenotransplantation, and human disease modeling. Finally, some bioethical and commercial concerns raised by the transgenesis applications are discussed.
\end{abstract}

Keywords: cloning, GMO, livestock, transgenesis.

\section{Introduction}

Transgenic animals and genetically modified organisms (GMOs) are organisms with a segment of foreign DNA incorporated into their genome, or with any modification introduced artificially in their genome sequence. Similarly to the technology of recombinant DNA, the GMOs have been studied for more than 30 years (Jackson et al. 1972; Cohen et al. 1973). Escherichia coli was the first genetically modified bacteria (Cohen et al. 1973). Since then, the technology of genetic manipulation of organisms has had a remarkable progress with a variety of bacteria, fungi, protists, plants and animals as GMOs. Regarding transgenic animals, the first genetically modified mouse was obtained by Jaenisch and collaborators 3 decades ago (Jaenisch et al. 1975). Even today, the mouse is the most important model for genetic studies in mammals. In 2002 the sequencing of the mouse genome was finished (Waterston et al. 2002), providing valuable knowledge for genetic engineering in livestock animals, such as cattle, pig, sheep and goats (Table 1). The initial effort of animal transgenesis was to produce pharmaceuticals on a large scale and at low cost through the injection of foreign DNA into a zygote pronucleus, but this technology has proved to be inefficient and expensive for large mono- ovulatory animals. The development of the nuclear transfer technique using mammal somatic cells (Wilmut et al. 1997) has opened a new perspective, allowing to generate transgenic livestock animals at lower time and costs (Polejaeva and Campbell 2000). Hence, a new era of animal transgenesis has been initiated, with special interest in modifications that improve quantitative and qualitative traits of livestock. The objective of this review is to present the most relevant advances in techniques of genetic engineering and its recent applications in livestock production. 
Table 1. Transgenic landmarks and reproductive technology in livestock animals (cattle, goats, sheep and swine)

\begin{tabular}{|c|c|c|}
\hline Year & Important transgenic landmarks & Reference \\
\hline 1985 & transgenic pig and sheep & Hammer et al. (1985) \\
\hline 1986 & embryonic cloning by nuclear transfer in sheep & Willadsen (1986) \\
\hline \multirow[t]{2}{*}{1991} & transgenic dairy cattle & Krimpenfort et al. (1991) \\
\hline & transgenic sheep producing altered milk & Wright et al. (1991) \\
\hline 1992 & transgenic pigs resistant to viral infection & Muller et al. (1992) \\
\hline 1994 & pig expressing inhibitor of human complement system & Fodor et al. (1994) \\
\hline \multirow[t]{2}{*}{1997} & somatic cloning by nuclear transfer in sheep (Dolly) & Wilmut et al. (1997) \\
\hline & transgenic livestock production as a model of human disease & Petters et al. (1997) \\
\hline 1998 & transgenic cattle produced by nuclear transfer & Cibelli et al. (1998) \\
\hline 2000 & transgenic sheep produced gene targeting & McCreath et al. (2000) \\
\hline 2001 & "ecologically correct" transgenic pig & Golovan et al. (2001) \\
\hline \multirow[t]{2}{*}{2002} & production of biopolymer fiber from transgenic cells & Lazaris et al. (2002) \\
\hline & calf with human artificial chromosome & Kuroiwa et al. (2002) \\
\hline \multirow[t]{2}{*}{2003} & transgenic cattle producing altered milk proteins compounds & Brophy et al. (2003) \\
\hline & complete gene inactivation in pigs & Phelps et al. (2003) \\
\hline 2004 & sequential inactivation of 2 bovine genes & Kuroiwa et al. (2004) \\
\hline 2005 & transgenic cow resistant to bacterial infection (mastitis) & Wall et al. (2005) \\
\hline
\end{tabular}

\section{State of the art}

The first successfully reported foreign DNA transfer to a mammal with germ-line transmission was obtained by using a retrovirus (Jaenisch et al. 1975). Retrovirus is an RNA virus that can infect mammals, causing several diseases (like herpes, cancers and immunodeficiency syndromes). During infection the virus fuses with the cell membrane and when the viral RNA is in the cytoplasm, it is converted into a DNA molecule that integrates into the host-cell genome. Therefore the retrovirus is an efficient transgene-delivery vehicle and it has been used to infect the bovine embryo when injected into the perivitelline space, between the surface of the fertilized egg and the zona pellucida (Chan et al. 1998). However, DNA transfer by a retrovirus has some limitations, such as: (1) preferential integration of retroviruses into dividing cells; (2) recognition of specific target cells; and (3) high probability of chimeric animal production, which is incapable of transferring the transgene to the next generation. Actually, studies are continued with the use of lentivirus vectors (family Retroviridae) in order to overcome some of these limitations, since lentiviruses do not require dividing cells for their integration and have a wide spectrum of target hosts cells. Nevertheless some lentiviruses cause serious infectious diseases, e.g. the equine infectious anemia virus (AIEV) and the immunodeficiency viruses of cattle and man (BIV and HIV, respectively). That still hinders the commercial production of transgenic livestock by this technology (Clark and Whitelaw 2003).

The sperm-mediated DNA transfer in rabbits, during in vitro fertilization, was the pioneer experiment to produce transgenic animals (Brackett et al. 1971). However, the generated animals were generally mosaic for the transgenes, so the genes were not always expressed in the second generation. The transformed sperm have been used for in vitro fertilization (Maione et al. 1998). Nevertheless this technique has a limited capability to incorporate the DNA into the host genome. In order to improve the DNA incorporation it is possible to expose the sperm to electrical field (electroporation), which has brought good results in cattle (Rieth et al. 2000; Celebi et al. 2003).

An alternative technique of sperm-mediated DNA transfer is through male germinal stem (GS) cell transfection and transplantation into the recipient seminiferous tubules (Nagano et al. 2001). This technique was first utilized in mice and recently has been successfully introduced in goats and pigs (Honaramooz et al. 2002, 2003). Almost 
$5 \%$ of the male progeny from mice transplanted with transformed GS cells were transgenic and transmitted the gene to subsequent generations (Nagano et al. 2001), making this methodology very promising.

The production of transgenic animals by embryonic stem (ES) cells, generates chimeric embryos composed of 2 distinct cell lines, and 1 of them carries the desired gene(s). ES cell lines are pluripotent cells derived from the inner cell mass of the blastocysts, and are capable of producing all tissues of an individual, including the germinative tissue. This gene transfer method involves the injection of transgenic ES cells into expanded blastocysts, and was first utilized in mice. This method is feasible in all animals in which ES cells can be manipulated and transfected in vitro (Robertson et al. 1986). Mice were the first mammals from which ES cells were isolated and cultured (Evans and Kaufman 1981; Martin 1981). Some of their advantages for the production of transgenic animals include the fact that ES cell lines can be targeted through homologous DNA recombination, which can be screened and selected for the incorporation of the foreign DNA before the transgenic embryo production. Moreover, the site of transgenic integration in the genome can be controlled to replace existing genes. Hence human gene function can be studied by knockout or knockin of candidate genes (Thomas and Capecchi 1987; Capecchi 1989). One of the limitations of this technique to produce transgenic livestock is that chimeric products must be crossbred to carry the transgene in all tissues, which can take a long time in animals like cattle. Additionally, the isolation and establishment of the livestock ES cell culture in vitro are still an incipient techniques for some species, like swine and cattle, and further studies are needed to fully establish the proper in vitro manipulation of ES cells from such species (Shim et al. 1997; Saito et al. 2003).

Another method for introducing foreign genes into animals is by direct pronuclear injection, where the gene of interest is directly injected into one of the pronuclei of a zygote. This technique was first developed in mice (Gordon and Ruddle 1981; Palmiter et al. 1982) and is still the main choice in production of transgenic rodents. Subsequently, the pronuclear injection was responsible for the first successful attempt to produce transgenic livestock species (including rabbits, sheep and swine) with the rat and human growth hormone gene (Hammer et al. 1985), as well as the first transgenic bovine (Krimpenfort et al. 1991). However, this technique has serious limitations, such as: (1) impossibility to produce knockouts by homologous recombination; (2) inefficiency in generating embryos in which the injected DNA was stably integrated into the host genome (Nottle et al. 2001); and (3) production of chimeric transgenic embryos resulting in a mosaic animal with some cells containing the transgene and others not (Keefer 2004); (4) unpredictability of the site of transgene integration in the host genome and the resulting variation in transgene expression because of the position effect (Clark et al. 1994). Due to the low efficiency of this technique, around 1000 bovine, and 300 ovine, and 200 goat zygotes must be microinjected to produce one founder transgenic animal (Seidel 1993), so this increases the costs of producing large transgenic animals.

Recently, the first successful nuclear transfer (NT) using somatic cells from the mammary gland has lead to the birth of the famed clone Dolly (Wilmut et al. 1997). In this method, DNA from the MII oocytes is removed (enucleation), leaving only the cytoplasm (the cytoplast). Following enucleation a donor nucleus, which can be almost any cell of the body, is injected into the perivitelline space and fused to the cytoplast by electrofusion. After fusion, the zygote clone is activated by either chemical or mechanical stimulation in order to initiate embryo development (Campbell et al. 1996; Wilmut et al. 1997). This process is known as cloning, since a series of identical individuals can be generated from a single DNA donor cell line.

The great impact of NT on transgenic livestock production is due to the possibility to cultivate primary cells in vitro during a long lifespan without loss of viability (Kasinathan et al. 2001a), and to execute the genetic manipulation before NT in order to produce transgenic embryos with the same rate of non-transgenic ones (Iguma et al. 2005). However, a good cell transfection system and the isolation of a transgenic cell line derived from a unique transfection event (clonal origin) must be efficiently conduced before the NT (Melo et al. 2005). A variety of methods for transfection into mammalian cells have been reported: microinjection (Sikes et al. 1994), particle bombardment (Williams et al. 1991), calcium phosphate (Chen and Okayama 1988), viral infection (Kovesdi et al. 1997), and liposomes (Caplen et al. 1995). However, the easy cell manipulation and the uniform transfection efficiency make the cationic liposome-mediated 
gene transfer the most appropriate method for many livestock species (Oliveira et al. 2005).

The NT associated with in vitro cell culture manipulation resulted in the first livestock animal (sheep) expressing human clotting Factor IX (Schnieke et al. 1997). Afterwards, 5 transgenic bovine clones resistant to antibiotic G418 were successfully produced by NT (Cibelli et al. 1998). Since then, many other transgenic animals have been generated by this technique (Keefer 2004; Kues and Niemann 2004). A great advantage of producing transgenic animals by NT, in comparison to pronuclear microinjection, is the possibility of gene targeting through homologous recombination between the exogenous and the host DNA producing knockouts and knockins (McCreath et al. 2000). Although being a recent technique, with low efficiency, the NT associated with transgenesis enables the production of transgenic embryos without chimeric hazards. Then, it is expected that all generated embryos will be transgenic, reducing the time and the cost of transgenic animal production, compared to other methods (Polejaeva and Campbell 2000; Melo et al. 2005). In order to increase the production of clones by NT, the use of synchronized G1 fibroblasts as nucleus donors (Kasinathan et al. 2001b; Gibbons et al. 2002), and treatment of nucleus donors by mitotic cell extracts to improve the nucleus reprogramming, are currently in use (Sullivan et al. 2004). At present, NT associated with transfection of cells cultured in vitro is the most important technique to obtain transgenic livestock.

\section{Applications}

Since the first reports about transgenic animals, published in the late 1970's and early 1980's, a variety of technical applications of transgenic animals have been suggested. Many of those applications are still waiting for scientists and entrepreneurs to solve technical challenges, and probably some of them will never be applied. However, several studies have been done and very soon products of transgenic livestock technology will be in the market. In the following sections of this article, we focus on 4 major fields of transgenic livestock applications: production of pharmaceuticals and biomolecules, livestock production, xenotransplants, and transgenic animals as a model for human diseases. However, our main goal is not to present general information about livestock transgenesis, but only the recent work that has shown the development of promising products, which are likely to be in the market in the near future.

\section{Production of pharmaceuticals and biomolecules}

Due to the high cost, the production of transgenic animals such as pig, goat, sheep and cattle must bring an elevated profit in order to be a feasible economical investment. For this reason, the production of high-value pharmaceutical substances, which correspond to a billion dollars market (Wall et al. 1997; Miller 2002), is actually the principal and most promising application for animal transgenesis. Despite the lower costs of producing biomolecules in microorganisms, like bacteria and yeast, these organisms do not properly execute several post-translational modifications, such as $\mathrm{N}$-linked glycosylations, authentic $O$-linked glycosylations, and correct folding in order to produce a wide range of fully active human proteins. Therefore, many human polypeptides must be produced in mammalian cell systems to be recovered with their full activities. However, principally due to the low productive capacity, the price of human biomolecules produced in vitro by mammalian cell culture is extremely high. For this reason many biotechnology companies have been focusing on the production of biopharmaceuticals, at high concentrations, in transgenic livestock bioreactors. Worldwide those companies are investing great effort in this promising technology. Among them we may mention PPL Therapeutics (UK), GTC Biotherapeutics (USA), Hematech (USA), Genzyme (USA), ZymoGenetics (USA), Nexia Biotechnologies (Canada), Pharming (Netherlands), BioProtein Technologies (France), Avigenics (USA), Viragen (USA), and TranXenoGen (USA). Pharmaceutical products can be produced in a variety of biological fluids such as milk, urine, saliva, blood and seminal fluid (Dyck et al. 2003), and their expression can be driven by tissue-specific promoters. Generation of transgenic mice expressing therapeutic heterologous proteins in urine, such as human recombinant erythropoietin (rhEPO) and human alpha1-antitrypsin (alpha1AT), using a uromodulin promoter has been demonstrated recently (Zbikowska et al. 2002a; Zbikowska et al. 2002b). Protein expression into the urine-based system has some advantages, including the expression in both sexes; low contaminant-protein content in urine; it can be harvested soon after birth and expressed throughout the life of the transgenic animal. However, the use of this system may be significantly more time- and cost-consuming than the mammary gland- based system. 
Due to its large-scale volume production, milk is the preferred vehicle to express proteins in transgenic animals. Table 2 lists biomolecules expressed in the mammary glands of livestock, which are at an advanced stage of clinical trials, and the respective holders of their commercial rights. The mammary gland can express more than $2 \mathrm{~g}$ of heterologous recombinant proteins per liter of milk (Velander et al. 1992; van Berkel et al. 2002). Based on the assumption of average expression levels, daily milk volumes and purification efficiency, 5400 cows would be needed to produce the $100000 \mathrm{~kg}$ of human serum albumin that are required worldwide per year, 4500 ewes would be required for the production of $5000 \mathrm{~kg}$ of $\alpha$-antitrypsin, 100 goats for $100 \mathrm{~kg}$ of monoclonal
$0.5-1.0 \mu \mathrm{g} \mathrm{mL}^{-1}$ from $\mathrm{F} 1$ females during lactation. A further study using the same animals has demonstrated the stability of transgenesis insertion at the chromatin level (Michalak et al. 2006). Besides the fact that foreign DNA was integrated into the rabbit genome in many copies, those authors showed that the hGH transgene was only actively expressed in the mammary gland. However, problems regarding regulatory elements required for a high expression level of genes encoding milk protein still need to be investigated.

Some biopharmaceutical products are well-advanced in clinical trials or are to be regulated by the US Food and Drug Administration (FDA), such as: (1) the production of antithrombin III in dairy goats (GTC Biotherapeutics),

Table 2. Human proteins secreted in the milk of transgenic livestock

\begin{tabular}{|c|c|c|c|c|}
\hline Pharmaceutical & Bioreactorspecies & Application/treatment & Company & Reference \\
\hline Antithrombin III & Goat & $\begin{array}{l}\text { thrombosis, pulmonary em- } \\
\text { bolism }\end{array}$ & GTC Biotherapeutics (USA) & $\begin{array}{l}\text { Ebert et al. (1991), } \\
\text { Denman et al. (1991) }\end{array}$ \\
\hline tPA & goat & thrombosis & PPL Therapeutics (UK) & Ebert et al. (1994) \\
\hline$\alpha$-antitrypsin & sheep & emphysema and cirrhosis & PPL Therapeutics (UK) & Wright et al. (1991) \\
\hline Factor IX & sheep & hemophilia b & PPL Therapeutics (UK) & Schnieke et al. (1997) \\
\hline Factor VIII & sheep & hemophilia a & PPL Therapeutics (UK) & $\begin{array}{l}\text { Paleyanda et al. (1997) } \\
\text { Niemann et al. (1999) }\end{array}$ \\
\hline $\begin{array}{l}\text { Polyclonal anti- } \\
\text { bodies }\end{array}$ & cattle & vaccines & Hematech (USA) & Kuroiwa et al. (2004) \\
\hline Lactoferrin & cattle & bactericide & Pharming Group (NED) & van Berkel et al. (2002) \\
\hline C1 inhibitor & rabbit & hereditary angioedema & Pharming Group (NED) & van Doorn et al. (2005) \\
\hline Calcitonin & rabbit & $\begin{array}{l}\text { osteoporosis and } \\
\text { hypercalcemia }\end{array}$ & PPL Therapeutics (UK) & McKee et al. (1998) \\
\hline
\end{tabular}

Note: The Pharming Group Co. is the current holder of most patents developed by PPL Therapeutics

antibodies, 75 goats for $75 \mathrm{~kg}$ of antithrombin III and two sows to produce $2 \mathrm{~kg}$ of human clotting factor IX required per year (Rudolph 1999). Therefore, a small herd of transgenic livestock could supply the world demand for pharmaceuticals, which cannot be expressed by other systems such as bacteria or fungi, mainly due to the necessity of complex post-translational possessing to ensure their proper function.

Studies have reported the use of transgenic rabbits, as bioreactors, using a rat whey acidic protein (WAP) promoter to produce the human growth hormone (hGH) in milk (Lipinski et al. 2003). In order to simplify the purification of the hGH, a sequence encoding 6 histidine residues and a site for thrombin digestion was added to the 5 ' end of the gene. The peptide was purified from milk by affinity chromatography, reaching a level of which is a potent inhibitor of the coagulation cascade used to treat patients with genetic heparin resistance and thrombosis; (2) the production of human polyclonal antibodies in cows aiming at therapeutic application (Hematech); (3) the production of human serum albumin in cows (GTC Biotherapeutics), which is a blood derivate with a high market price; (4) the production of $\alpha$-antitrypsin in sheep (PPL) for treatment of lung emphysema, cirrhosis, and cystic fibrosis; (5) the production of recombinant human factor IX protein in sheep (PPL) and human factor VIII in swine(Paleyanda et al. 1997) for the treatment of hemophilia B and A, respectively; (6) the production of human lactoferrin in cows (Pharming), which has a bacteriostatic, antiviral, and antifungal activity, and also acts as a natural stimulator of the innate immunological defense. Nevertheless, not 
all attempts to produce bioproducts in animal milk have been successful. Frequently the protein synthesized in milk causes side effects, such as for instance: (1) the erythropoietin effect leading to problems in hematopoiesis and rabbit fertility (Massoud et al. 1996); (2) the premature cessation of lactation in the goat expressing the tissue plasminogen activator (tPA) (Ebert et al. 1994); and (3) low yields of biologically active recombinant human factor VIII produced in sheep (Niemann et al. 1999).

The production of a transgenic animal expressing the bioactive recombinant protein with a concentration of at least $1 \mathrm{mg} \mathrm{mL} \mathrm{m}^{-1}$, and with the transgene stably transferred to the offspring, is a goal that requires a lot of time, knowledge, and effort (Wall et al. 1997). Moreover, another challenge regarding the production of recombinant proteins in milk is the purification process, where recombinant proteins must be isolated from several undesirable milk components. In order to clone goats that are capable of producing recombinant spider silk proteins in milk, Lazaris and collaborators (Lazaris et al. 2002) performed studies with epithelial cells from the mammary gland expressing spider thread genes. Afterwards, by purifying the recombinant proteins, those authors obtained spider silk fibers. Nevertheless, the fiber product did not meet the tenacity and resistance characteristics present in the natural spider silk. Therefore, the purification step might be critical to the generation of a feasible product.

\section{Livestock production}

The emergence of the first transgenic mice expressing the rat growth hormone fused to the metallothionein promoter sequence, during the 1980's (Palmiter et al. 1982), opened the possibility to use transgenesis as an instrument to increase meat production. However, high profits forecasted with the application of biopharmaceuticals set aside transgenic research to improve livestock production. On the other hand, the recent boom of biotechnology companies observed in the last decade, together with the enormous cost to produce a pharmaceutical in transgenic livestock, made this trade more competitive and less profitable. Facing this unfavorable view, PPL Therapeutics, the company that holds most of the patents on pharmaceuticals produced by transgenic livestock (Table 2), declared bankruptcy in 2004 because of financial difficulties (www.onescience.com/forum/). Nowadays, the US FDA demands a variety of clinical, labora- tory and environment trials bringing the average cost to place a new drug on the market upwards of US\$800 million. Moreover, the total time required for drug development, from the synthesis of the molecule to market approval is, right now, around 15 years (Miller 2002). The high competition and regulation of the pharmaceutical sector, together with the current progress in animal transgenesis techniques, allows a significant reduction in production costs, and has offered new prospects for transgenesis aiming at high productivity in livestock. Thus, the application of livestock transgenesis could promote the improvement of carcass composition, meat quality, milk production, wool quality, increased prolificacy and disease resistance, besides other economically important characteristics.

Milk is a complex biological fluid with significant importance as a food source for many societies. The annual production exceeds $400 \times 10^{9}$ liters and accounts for around US\$400 billion at the global dairy product market (Karatzas 2003). Approximately $80 \%$ of milk proteins are composed of caseins, which are the most valuable components of milk. The casein fraction of bovine milk is comprised by $\alpha_{\mathrm{S} 1^{-}}, \alpha_{\mathrm{S} 2^{-}}, \beta$ - and $\kappa$-casein, encoded by one-copy genes (Karatzas and Turner 1997). Caseins are aggregated into large colloidal micelles. The micelle structure and stability can be affected by small changes in the casein ratio, leading to substantial effects on the physicochemical properties of milk. Cheese is manufactured by the aggregation of casein micelles into protein networks that entrap some water and most of the fat from milk. Increased $\kappa$-casein content has been linked to a reduction of the micelle size and to improved heat stability, which are of huge importance in cheese making industry (Kang et al. 1986). Recently, genetically modified bovines were generated by introducing additional copies of genes CSN2 and CSN3, which encode bovine $\beta$ and $\kappa$-casein, respectively (Brophy et al. 2003). Overexpression of CSN2 and CSN3 resulted in an up to $20 \%$ increase in $\beta$-casein, and a 2 -fold increase in $\kappa$-casein levels in milk. These results demonstrated that it is possible to alter milk composition by the transgenic approach. Moreover, it also can increase the efficiency of cheese production, which is a billion dollar market.

Another target that can be altered is related to milk constituents. Around 70\% of the world population, especially from Asia, experience a deficiency in the lactase enzyme. This enzyme is responsible for lactose digestion (lactose is the 
main milk sugar), and a low expression of this enzyme can potentially limit milk consumption. In 1994, studies with $\alpha$-lactalbumin-deficient mice allowed the lactose synthase complex to be analyzed (Stinnakre et al. 1994). The results from these experiments showed a $20 \%$ reduction in milk lactose levels in mice with the monoallelic expression of the gene, while knockout mice produce no lactose (Stinnakre et al. 1994; Stacey et al. 1995). However, those mice demonstrated an intense modification in the physicochemical properties of their milk, which presented a rise in the total solids and a decrease in milk quantity. Despite these results, the market still has an economic interest in producing low-lactose milk using other techniques, such as the production of transgenic animals with a lactase enzyme gene, which is responsible for lactose degradation (Jost et al. 1999). An increase of milk production in pigs is also another goal to be reached, with an expected outcome of an improved value of the piglet per dam per year parameter. The selection pressure, in order to anticipate weaning, produces sows with a shorter lactation period. This leads to a negative effect in litter growth performance not only before weaning, but also persisting throughout the growing period until slaughter (Wheeler 2003). Due to the fact that enhanced $\alpha$-lactalbumin synthesis is closely correlated with an increase in milk production, copies of the bovine $\alpha$-lactalbumin genes were introduced in swine (Bleck et al. 1998). The results of this work showed an increased milk production during the first 9 days of lactation in transgenic sows, as well as a significant increase in piglet growth rate in transgenic gilts (Noble et al. 2002). This effect can easily mean a profit of millions of dollars for the pig industry.

The implications of modifying milk properties by transgenesis go beyond just dairy products. $\mathrm{Hu}-$ manized bovine and goat milk can bring several benefits to human health. An example of this is the expression of human lactoferrin in milk. Antibacterial, antifungal and antiviral proprieties have been demonstrated for human lactoferrin (Soukka et al. 1992; Hasegawa et al. 1994; Nibbering et al. 2001). Moreover, human lactoferrin stimulates the growth of the intestinal biota of healthy breast-fed infants, as well as promotes intestinal cell growth in vitro (Nuijens et al. 1997). The production of recombinant human lactoferrin in milk of 4 transgenic cows at a concentration of up to $2 \mathrm{mg} \mathrm{mL}^{-1}$ is a promising step to improve infant innate defense (van Berkel et al. 2002). Using DMSO-spermmediated gene transfer human lactoferrin was also expressed in transgenic rabbits, where $81 \%$ of transgenic females obtained could express human lactoferrin in their glands ( $\mathrm{Li}$ et al. 2006), with a mean expression level of $103 \pm 20 \mu \mathrm{g} \mathrm{mL} \mathrm{m}^{-1}$. However, this level of expression declined gradually after the third week.

The potential to increase disease resistance is another very important aspect of agricultural transgenic market. Mastitis is an inflammatory reaction of the mammary gland caused by a microbial infection. Five bacterial species are related to the bulk of bovine mastitis cases: Staphylococcus aureus, Streptococcus uberis, Streptococcus dysgalactiae, Streptococcus galactiae and Escherichia coli. However, S. aureus is responsible for the majority of the clinical cases and, because of its resistance to a variety of antibiotics, has been difficult to control (Kerr and Wellnitz 2003). Therefore, mastitis is one of the most harmful diseases for the dairy industry, and the estimated annual loss caused by this disease in the USA is over $\$ 1.7$ billion (Kerr and Wellnitz 2003). Lysostaphin is a potent peptidoglycan hydrolase naturally secreted by Staphylococcus simulans, and has a bactericidal effect against other Staphilococci, such as $S$. aureus. The efficacy of lysostaphin protection against $S$. aureus conferred to the mammary gland has been demonstrated using transgenic mice that expressed lysostaphin in the mammary gland cells (Kerr et al. 2001). Recently, the same research group obtained transgenic cows secreting lysostaphin at concentrations up to $14 \mathrm{mg} \mathrm{mL}^{-1}$ in their milk (Wall et al. 2005). Those authors also infiltrated $S$. aureus into the mammary glands of 3 transgenic and 10 nontransgenic cows. Although none of the transgenic animals showed mastitis symptoms, all of the nontransgenic cows developed mastitis.

The most feared bovine disease in countries of the Northern Hemisphere is bovine spongiform encephalopathy (BSE), also known as mad cow disease. This disease resulted in the cremation of millions of animals at an estimated final cost of billions of dollars in the United Kingdom (Detwiler and Rubenstein 2000). The cause of BSE probably lies in a mutation of the prion protein $\left(\operatorname{PrP}^{C}\right)$, which is found in the outer surface of neurons. This prion disease is generated by a switch from the normal $\operatorname{PrP}^{\mathrm{C}}$ to a modified form of $\operatorname{PrP}\left(\mathrm{PrP}^{\mathrm{SC}}\right)$. Healthy animals fed a diet supplement produced with animal by-products could develop BSE (Weissmann et al. 2002). During the early 1990's transgenic mice were generated by knocking out the $\operatorname{PrP}^{\mathrm{C}}$ gene (Bueler et al. 1992). 
The obtained mice presented normal development and were resistant to spongiform encephalopathy, even after inoculation with $\mathrm{PrP}^{\mathrm{SC}}$ prions (Bueler et al. 1993). Afterward, knockout of the prion gene in transgenic sheep and cattle have opened a new perspective to create animals non-susceptible to spongiform encephalopathy (Denning et al. 2001; Kuroiwa et al. 2004). Animals with deleted $\operatorname{PrP}^{\mathrm{C}}$ were generated by multiple gene targeting events, which removed not only the $\operatorname{PrP}^{\mathrm{C}}$ gene, but also changed the entire bovine immunoglobulin gene loci for the human correspondent. This manipulation makes it possible to produce human immunoglobulins in cattle safe from BSE (Kuroiwa et al. 2004).

Brucellosis is an important disease worldwide, caused by Brucella bacteria, some of the world's major zoonotic pathogens. Brucellosis resistant animals have been identified, and this resistance has been related to the presence of the NRAMP1 variant gene in bovine. Recently, the NRAMP1 gene was introduced into mice macrophage cell lines in order to evaluate its protection conferred during Brucella infection (Barthel et al. 2001). The introduction of the NRAMP1 allele offered new promising prospects for brucellosis resistance.

Improvement of carcass quality as well as meat production is an important application of transgenesis in livestock. One of the first attempts in this field was the production of mice that express the rat growth hormone. Those mice showed a remarkable increase in growth rate and body weight (Palmiter et al. 1982), and were the pioneer transgenic mice. However, transgenic pig expressing the growth hormone exhibited only a slight increase in growth and a high incidence of collateral effects, such as gastric ulcers, arthritis, cardiomegaly, dermatitis, and renal disease (Pursel et al. 1989). Studies performed in the Belgian Blue and Piedmontese bovine breeds revealed that mutations in the myostatin gene (GDF-8) are related to the double-muscled phenotype (Grobet et al. 1997; McPherron and Lee 1997). Myostatin is a negative regulator of skeletal muscle mass in mammals, and its deficiency leads to a dramatic and widespread increase in skeletal muscle mass. Myostatin null mice generated by gene targeting demonstrated the same double-muscling phenotype observed in bovine (McPherron et al. 1997). Muscles in myostatin null mice weighed 2 to 3 times more than their counterparts in wild-type mice. Those studies reported that the myostatin gene is highly conserved among vertebrate species and have offered new prospects for transgenic animals with this phenotype.

Characteristics such as prolificity may be perceived as one of the many transgenic applications. Some sheep breeds present multiple ovulations due to the mutations in genes involved in follicular development and growth, such as GDF9, BMP15 and ALK6/BMPR1B (Souza et al. 2001; Juengel et al. 2002; Hanrahan et al. 2004). Furthermore, production of bulls expressing "suicide genes", which are capable of generating just spermatozoids with the $\mathrm{X}$ chromosome or even sheep with higher quality and quantity of wool (Powell et al. 1994) are other possible applications of animal transgenesis. The production of transgenic pigs expressing salivary phytase would provide essentially complete digestion of dietary phosphorus, reducing phosphorus output by up to $75 \%$ (Golovan et al. 2001). Therefore, the use of these transgenic pig could result in a significant decrease of phosphorus pollution from pig industry, with a great impact on the reduction of environmental pollution. Nowadays, many applications in animal livestock transgenesis have been explored and soon some of them will be ready to use.

\section{Xenotransplant}

Due to successful transplants of human organs (allotransplants), roughly 250000 people are alive today. Around $75-90 \%$ of patients survive the first year after transplant. The average survival rate of a heart, liver or kidney transplanted patient is about 10-15 years (Kues and Niemann 2004). Nevertheless, the availability of organ donors is always insufficient in relation to the number of patients that need transplants. The National Transplant System in Brazil, created in 1997, has performed more than 60000 transplants. However, 63000 patients are still on the waiting lists and need to be attended urgently (http://dtr2001. saude.gov.br/transplantes). In the USA the waiting list exceeds 88000 patients and the ratio between donor organs and patients is $1: 4$ (http://www.unos.org). Therefore, an alternative source of organ donors could reduce the growing gap between the demand and the availability of organs. The possibility of xenotransplants as an alternative source of organs has been investigated for decades. In 1963, a kidney transplant from a chimpanzee to a human was the first attempt of a xenotransplant (reviewed in Auchincloss and Sachs 1998). Nowadays, studies have shown that the pig is the animal considered the best choice 
as an organ donor for humans. This fact is based on: (1) their organs being similar in size, anatomy and physiology to human organs; (2) pigs growing rapidly and being a prolific species; (3) the maintenance of high hygienic standards possible at a relatively low cost; (4) established transgenic techniques to modify immunogenicity of porcine cells and organs. The main immunologic obstacles to xenotransplants include the hyperacute rejection response (HAR), which occurs within seconds or minutes, the acute vascular rejection (AVR), which occurs within days, and the cellular and potentially chronic rejection, which occurs within weeks after the transplant (Auchincloss and Sachs 1998). Several transgenic approaches have been developed to overcome the immunological response that activates the complement cascade, which is activated by the antigen-antibody complex and is responsible for the induction of HAR and AVR. The production of a transgenic pigs, expressing human proteins that inhibit the complement cascade such as hCD59 (Fodor et al. 1994), hCD46 (Diamond et al. 2001) and hDAF (Zaidi et al. 1998), are examples of attempts to overcome this problem. In those experiments a survival rate of 23 days was reached when transplanting a transgenic pig heart into primates (Diamond et al. 2001). Another promising strategy to avoid HAR is the knockout of antigenic structures on the surface of porcine organs such as 1,3- $\alpha$-gal-epitopes, absent in the human species. 1,3- $\alpha$-gal-epitopes are primarily produced by the activation of 1,3- $\alpha$-galactosyltransferase. Transgenic piglets with a disruption of both alleles of 1,3- $\alpha$ galactosyltransferase by homologous recombination were generated and their use have been reported (Phelps et al. 2003). Xenotransplants using transgenic bovine nervous-system cells were successfully used to reduce the symptoms of Parkinson's disease in rat models (Zawada et al. 1998). Likewise, transgenic pig neurons promoted axonal regeneration in rat spinal cord lesions (Imaizumi et al. 2000). Nevertheless, the prevention of zoonosis transmission is a critical point for the clinical application of xenografts. In 1997, it was reported by an in vitro assay that the PERV retrovirus, carried by porcine host cells, could infect human cell lines (Patience et al. 1997), but a subsequent study did not detect the presence of PERV in patients, that had received porcine tissues transplants, for up to 12 years (Patience et al. 1998; Paradis et al. 1999). However, during the past few years, the accelerated progress in human stem-cell research, as a way of in vitro production of human tissue and organs for transplants, significantly reduced the effort into xenotransplant research as a safer and more promising technology (for an updated review see Wobus and Boheler 2005).

\section{Transgenic animals as a model for human diseases}

There are around 20 000-25 000 human genes responsible for the formation and maintenance of human body (Human Genome Sequencing 2004). So far, thousands of human diseases have been characterized based on Mendelian genetic inheritance (OMIM 2006). Many of these diseases are caused by genetic mutations already characterized in mice models by knockout through gene targeting. Those animals are valuable experimental models to study the symptoms and causes of a variety of human diseases, such as cancer (Marx 2003). However, mouse anatomy, physiology and lifespan differ significantly from those of humans. Therefore, the use of mice as a genetic model has shown some limitations regarding the study of several human traits. Hence, farm animals, such as pigs, sheep or cattle, could be more appropriate models to avoid some problems, for example, the requirement of longer observation periods in studies of many human diseases. The use of transgenic pigs as experimental models was an advance in the study of retinitis pigmentosa, a rare human syndrome. Transgenic pigs express a mutated rhodopsin gene, responsible for night blindness, and show a great similarity with the human phenotype (Petters et al. 1997). The alteration of the growth hormone releasing hormone (GHRH), which is observed in patients with Turner's syndrome, Crohn's disease, renal insufficiency, and intrauterine growth retardation, was also studied in a porcine model (Draghia-Akli et al. 1999). A diversity of neurodegenerative human disorders such as the Gerstmann-Straussler-Scheinker syndrome, Creutzfeldt-Jakob disease or fatal familial insomnia were related to a defective prion protein $\left(\operatorname{PrP}^{\mathrm{C}}\right)$ gene. Deletions in the $\operatorname{PrP}^{\mathrm{C}}$ allele using mice or cattle models can be useful models to study related anomalies (Bueler et al. 1992; Kuroiwa et al. 2004), and also create resistant animals (Bueler et al. 1993).

Another promising research field using transgenic animals as models is the study of ageing. Telomeres are highly repetitive DNA sequences present at the end of all chromosomes, and are essential for their structural integrity and function. As DNA replicates, during successive mitoses, the telomere structure has its size continuously re- 
duced. Telomere shortening is correlated with severe limitations of the regenerative capacity of cells and ageing, with a significant impact on human lifespan (Djojosubroto et al. 2003). Human telomerase reverse transcriptase (hTERT) plays a role in promoting telomere revitalization and cell proliferation. Delivery of the hTERT gene by an adenovirus has been shown to improve ischemic wound healing in an aged rabbit model (Mogford et al. 2006). Furthermore, no deleterious immune response was induced in aged rabbits, being an important implication for the field of gene therapy.

Many cancer cell lines showed alterations in the size and structure of their telomeres, and this fact can be related to the origin of some types of cancer (Rudolph et al. 2001; Cawthon et al. 2003). The TERT enzyme, which is responsible for the formation and rebuilding of telomeres, is postnatally suppressed in most somatic cells (Djojosubroto et al. 2003). Symptoms of early ageing were observed in cloned sheep (Dolly) and were related to telomere shortening. The hypothesis was that Dolly could have inherited the adult cell telomere size and could have been born as being of the same biological age as the original mammary gland cells, used as DNA donors (Shiels et al. 1999). However, studies in mice and cattle refuted this hypothesis, showing that telomeres can regenerate during successive cloning of senescent donor cells, with no difference in age from the matched controls (Lanza et al. 2000; Wakayama et al. 2000). This observation may be explained by recent studies that have showed the reactivation of clone embryo telomerase, during the nuclear reprogramming process, where the original telomere size could be restored (Betts et al. 2001). Further investigations on telomerase gene mutations will broaden our knowledge on cancer and ageing.

Nowadays the vascular endothelial growth factor (VEGF) is one of the most important pro-angiogenic cytokines. It has been used largely to stimulate therapeutic angiogenesis. One of the investigations in this field reported the use of transgenic rabbits to express in vivo recombinant VEGF in the carotid artery (Suda et al. 2005). The study suggested that the expression of recombinant VEGF in the vascular endothelium stimulates the generation of the superoxide anion in the arterial wall. This is an important finding for the treatment of cardiovascular diseases, since the superoxide anion seems to be a significant mediator of the regenerative vascular effects of VEGF in vivo.

\section{Concerns and prospects for the future}

Since the domestication of first animals humans have been introducing genetic modifications by assisted breeding in a variety of species. Currently, the major difference observed between genetically modified species and their wild relatives is not due to the transgene effect, but to the profound alterations that were introduced during the domestication process. It also reflects a continuous co-evolution of the human society and the domesticated organisms, such as plants, animals, and microorganisms. Those modifications were most often performed based on the observation of the phenotype without any knowledge on inheritance mechanisms behind selection. Nowadays with the advances of scientific knowledge we can have a better understanding of inheritance mechanisms and make punctual and specific alterations in DNA sequences to meet our requirements. Therefore, discussions on ethics arising with the first GMOs demonstrated the continuity of the human activity in altering the environment, as well as organisms, for our own benefit. Notwithstanding, it does not exempt us from the responsibility for our actions and a recent research field, named biosafety, has been created to manage the ecological impact of GMOs.

Regarding individual characteristics of livestock, although we have to consider the low response to artificial selection compared to changes obtained with transgenesis, a continuous application of the former for many generations can introduce huge genetic modifications. Therefore, when an animal is out of a genetic breeding program, in order to insert any genetic modification, the result is an intrinsic loss of the productive ability conferred to their assisted selected counterparts. The time estimated to generate transgenic livestock, e.g. cattle, is about 5-7 years. Taking this in consideration, the economic profit introduced by the new characteristic should be significant to compensate for the loss of productivity provoked by the exclusion from the artificial selection program (Karatzas and Turner 1997; Clark and Whitelaw 2003). Moreover, the high cost involved in the transgenic process allows us to obtain only few animals for each genetic modification event. For this reason, a laborious process of reintroduction of those animals in the herd by backcrossing is required. In order to make this process economically feasible, it is essential to have in-depth knowledge about the recent advances in assisted reproduction techniques, such as artificial insemination associated with embryo transfer, or in vitro 
embryo production. Nevertheless, some degree of inbreeding is inevitable, which leads to a loss of genetic variability.

Another consequence of the introduction of new characteristics to a livestock product, e.g. milk or meat, is the public perception related to the emergence of new products on the market. The pharmaceutical industry has a history of obtaining products through a variety of microorganisms, plants, animals and human tissue sources. Therefore, the isolation of biopharmaceutical products from milk derived from genetically modified animals does not require significant changes in the production system or market perception by the consumers. However, the prospect of livestock animals with new properties and characteristics would have an enormous impact on the structure of agricultural industry. For example, the goal for dairy industry has been high milk production to meet the consumers' demand. Nevertheless, transgenesis can offer the possibility for dairy producers to have milk with higher $\beta$-casein levels, which is good for cheese production, or milk with specific characteristics to supply population deficiencies, such as: lactose-free milk, destined for the Asian market; milk without lactoglobulin destined for allergic consumers; or milk with the human lactoferrin protein, to ensure newborns' health. As a result new niches would be created and, consequently, the market will be segmented, revolutionizing the entire milk production chain. The benefits of this segmentation can be confirmed by the profitable market of crops in the agriculture sector. But a question remains: is the livestock industry prepared for such changes? This and other questions will be answered as the technical and scientific progress reduces the costs of transgenic livestock and makes it even more feasible and accessible for the production sector.

Acknowledgments. We thank Roberto Sartori and Margot A.N. Dode for their helpful assistance and comments.

\section{REFERENCES}

Auchincloss H, Jr., Sachs DH, 1998. Xenogeneic transplantation. Annu Rev Immunol 16: 433-470.

Barthel R, Feng J, Piedrahita JA, McMurray DN, Templeton JW, Adams LG, 2001. Stable transfection of the bovine NRAMP1 gene into murine RAW264.7 cells: effect on Brucella abortus survival. Infect Immun 69: 3110-3119.

Betts D, Bordignon V, Hill J, Winger Q, Westhusin M, Smith L, King W, 2001. Reprogramming of telomerase activity and rebuilding of telomere length in cloned cattle. Proc Natl Acad Sci USA 98: 1077-1082.

Bleck GT, White BR, Miller DJ, Wheeler MB, 1998. Production of bovine alpha-lactalbumin in the milk of transgenic pigs. J Anim Sci 76: 3072-3078.

Brackett BG, Baranska W, Sawicki W, Koprowski H, 1971. Uptake of heterologous genome by mammalian spermatozoa and its transfer to ova through fertilization. Proc Natl Acad Sci USA 68: 353-357.

Brophy B, Smolenski G, Wheeler T, Wells D, L'Huillier P, Laible G, 2003. Cloned transgenic cattle produce milk with higher levels of beta-casein and kappa-casein. Nat Biotechnol 21: 157-162.

Bueler H, Aguzzi A, Sailer A, Greiner RA, Autenried P, Aguet M, Weissmann C, 1993. Mice devoid of $\operatorname{PrP}$ are resistant to scrapie. Cell 73: 1339-1347.

Bueler H, Fischer M, Lang Y, Bluethmann H, Lipp HP, DeArmond SJ, et al. 1992. Normal development and behaviour of mice lacking the neuronal cell-surface PrP protein. Nature 356: 577-582.

Campbell KH, McWhir J, Ritchie WA, Wilmut I, 1996. Sheep cloned by nuclear transfer from a cultured cell line. Nature 380: 64-66.

Capecchi MR, 1989. Altering the genome by homologous recombination. Science 244: 1288-1292.

Caplen NJ, Kinrade E, Sorgi F, Gao X, Gruenert D, Geddes D, et al. 1995. In vitro liposome-mediated DNA transfection of epithelial cell lines using the cationic liposome DC-Chol/DOPE. Gene Ther 2: 603-613.

Cawthon RM, Smith KR, O'Brien E, Sivatchenko A, Kerber RA, 2003. Association between telomere length in blood and mortality in people aged 60 years or older. Lancet 361: 393-395.

Celebi C, Guillaudeux T, Auvray P, ValletErdtmann V, Jegou B, 2003. The Making of "Transgenic Spermatozoa". Biol Reprod 68: 1477-1483.

Cibelli JB, Stice SL, Golueke PJ, Kane JJ, Jerry J, Blackwell C, et al. 1998. Cloned transgenic calves produced from nonquiescent fetal fibroblasts. Science 280: 1256-1258.

Chan AW, Homan EJ, Ballou LU, Burns JC, Bremel RD, 1998. Transgenic cattle produced by reverse-transcribed gene transfer in oocytes. Proc Natl Acad Sci USA 95: 14028-14033.

Chen CA, Okayama H, 1988. Calcium phosphate-mediated gene transfer: a highly efficient transfection system for stably transforming cells with plasmid DNA. Biotechniques 6: 632-638.

Cibelli JB, Stice SL, Golueke PJ, Kane JJ, Jerry J, Blackwell C, et al. 1998. Cloned transgenic calves produced from nonquiescent fetal fibroblasts. Science 280: 1256-1258.

Clark AJ, Bissinger P, Bullock DW, Damak S, Wallace R, Whitelaw CB, Yull F, 1994. Chromosomal position effects and the modulation of transgene expression. Reprod Fertil Dev 6: 589-598. 
Clark J, Whitelaw B, 2003. A future for transgenic livestock. Nat Rev Genet 4: 825-833.

Cohen SN, Chang AC, Boyer HW, Helling RB, 1973. Construction of biologically functional bacterial plasmids in vitro. Proc Natl Acad Sci USA 70: 3240-3244.

Denman J, Hayes M, O’Day C, Edmunds T, Bartlett C, Hirani S, et al. 1991. Transgenic expression of a variant of human tissue-type plasminogen activator in goat milk: purification and characterization of the recombinant enzyme. Biotechnology (NY) 9: 839-843.

Denning C, Burl S, Ainslie A, Bracken J, Dinnyes A, Fletcher J, et al. 2001. Deletion of the alpha $(1,3)$ galactosyl transferase (GGTA1) gene and the prion protein (PrP) gene in sheep. Nat Biotechnol 19: 559-562.

Detwiler LA, Rubenstein R, 2000. Bovine spongiform encephalopathy: an overview. Asaio J 46: S73-79.

Diamond LE, Quinn CM, Martin MJ, Lawson J, Platt JL, Logan JS, 2001. A human CD46 transgenic pig model system for the study of discordant xenotransplantation. Transplantation 71: 132-142.

Djojosubroto MW, Choi YS, Lee HW, Rudolph KL, 2003. Telomeres and telomerase in aging, regeneration and cancer. Mol Cells 15: 164-175.

Draghia-Akli R, Fiorotto ML, Hill LA, Malone PB, Deaver DR, Schwartz RJ, 1999. Myogenic expression of an injectable protease-resistant growth hormone-releasing hormone augments long-term growth in pigs. Nat Biotechnol 17: 1179-1183.

Dyck MK, Lacroix D, Pothier F, Sirard MA, 2003. Making recombinant proteins in animals - different systems, different applications. Trends Biotechnol 21: 394-399.

Ebert KM, Selgrath JP, DiTullio P, Denman J, Smith TE, Memon MA, et al. 1991. Transgenic production of a variant of human tissue-type plasminogen activator in goat milk: generation of transgenic goats and analysis of expression. Biotechnology (NY) 9: 835-838.

Ebert KM, DiTullio P, Barry CA, Schindler JE, Ayres SL, Smith TE, et al. 1994. Induction of human tissue plasminogen activator in the mammary gland of transgenic goats. Biotechnology (NY) 12: 699-702.

Evans MJ, Kaufman MH, 1981. Establishment in culture of pluripotential cells from mouse embryos. Nature 292: 154-156.

Fodor WL, Williams BL, Matis LA, Madri JA, Rollins SA, Knight JW, et al. 1994. Expression of a functional human complement inhibitor in a transgenic pig as a model for the prevention of xenogeneic hyperacute organ rejection. Proc Natl Acad Sci USA 91: 11153-11157.

Gibbons J, Arat S, Rzucidlo J, Miyoshi K, Waltenburg R, Respess D, et al. 2002. Enhanced survivability of cloned calves derived from roscovitine-treated adult somatic cells. Biol Reprod 66: 895-900.

Golovan SP, Meidinger RG, Ajakaiye A, Cottrill M, Wiederkehr MZ, Barney DJ, et al. 2001. Pigs ex- pressing salivary phytase produce low-phosphorus manure. Nat Biotechnol 19: 741-745.

Gordon JW, Ruddle FH, 1981. Integration and stable germ line transmission of genes injected into mouse pronuclei. Science 214: 1244-1246.

Grobet L, Martin LJ, Poncelet D, Pirottin D, Brouwers B, Riquet J, et al. 1997. A deletion in the bovine myostatin gene causes the double-muscled phenotype in cattle. Nat Genet 17: 71-74.

Hammer RE, Pursel VG, Rexroad CE, Jr., Wall RJ, Bolt DJ, Ebert KM, et al. 1985. Production of transgenic rabbits, sheep and pigs by microinjection. Nature 315: 680-683.

Hanrahan JP, Gregan SM, Mulsant P, Mullen M, Davis GH, Powell R, Galloway SM, 2004. Mutations in the genes for oocyte-derived growth factors GDF9 and BMP15 are associated with both increased ovulation rate and sterility in Cambridge and Belclare sheeo (Ovis aries). Biol Reprod 70: 900-909.

Hasegawa K, Motsuchi W, Tanaka S, Dosako S, 1994. Inhibition with lactoferrin of in nitro infection with human herpes virus. Jpn J Med Sci Biol 47: 73-85.

Honaramooz A, Behboodi E, Blash S, Megee SO, Dobrinski I, 2003. Germ cell transplantation in goats. Mol Reprod Dev 64: 422-428.

Honaramooz A, Megee SO, Dobrinski I, 2002. Germ cell transplantation in pigs. Biol Reprod 66: 21-28.

Human Genome Sequencing C, 2004. Finishing the euchromatic sequence of the human genome. Nature 431: 931-945.

Iguma LT, Lisauskas SF, Melo EO, Franco MM, Pivato I, Vianna GR, et al. 2005. Development of bovine embryos reconstructed by nuclear transfer of transfected and non-transfected adult fibroblast cells. Genet Mol Res 4: 55-66.

Imaizumi T, Lankford KL, Burton WV, Fodor WL, Kocsis JD, 2000. Xenotransplantation of transgenic pig olfactory ensheathing cells promotes axonal regeneration in rat spinal cord. Nat Biotechnol 18: 949-953.

Jackson DA, Symons RH, Berg P, 1972. Biochemical method for inserting new genetic information into DNA of Simian Virus 40: circular SV40 DNA molecules containing lambda phage genes and the galactose operon of Escherichia coli. Proc Natl Acad Sci USA 69: 2904-2909.

Jaenisch R, Fan H, Croker B, 1975. Infection of preimplantation mouse embryos and of newborn mice with leukemia virus: tissue distribution of viral DNA and RNA and leukemogenesis in the adult animal. Proc Natl Acad Sci USA 72: 4008-4012.

Jost B, Vilotte JL, Duluc I, Rodeau JL, Freund JN, 1999. Production of low-lactose milk by ectopic expression of intestinal lactase in the mouse mammary gland. Nat Biotechnol 17: 160-164.

Juengel JL, Hudson NL, Heath DA, Smith P, Reader KL, Lawrence SB, et al. 2002. Growth differentiation factor 9 and bone morphogenetic protein 15 are essential for ovarian follicular development in sheep. Biol Reprod 67: 1777-1789. 
Kang Y, Jimenez-Flores R, Richardson T, 1986. Casein genes and genetic engineering of the caseins. Basic Life Sci 37: 95-111.

Karatzas CN, 2003. Designer milk from transgenic clones. Nat Biotechnol 21: 138-139.

Karatzas CN, Turner JD, 1997. Toward altering milk composition by genetic manipulation: current status and challenges. J Dairy Sci 80: 2225-2232.

Kasinathan P, Knott JG, Moreira PN, Burnside AS, Jerry DJ, Robl JM, 2001a. Effect of fibroblast donor cell age and cell cycle on development of bovine nuclear transfer embryos in vitro. Biol Reprod 64: 1487-1493.

Kasinathan P, Knott JG, Wang Z, Jerry DJ, Robl JM, 2001b. Production of calves from G1 fibroblasts. Nat Biotechnol 19: 1176-1178.

Keefer CL, 2004. Production of bioproducts through the use of transgenic animal models. Anim Reprod Sci 82-83: 5-12.

Kerr DE, Plaut K, Branley AJ, Williamson CM, Lax AJ, Moore K, et al. 2001. Lysostaphin expression in mammary glands confers protection against staphylococcal infection in transgenic mice. Nat Biotechnol 19: 66-70.

Kerr DE, Wellnitz O, 2003. Mammary expression of new genes to combat mastitis. J Anim Sci 81: 38-47.

Kovesdi I, Brough DE, Bruder JT, Wickham TJ, 1997. Adenoviral vectors for gene transfer. Curr Opin Biotechnol 8: 583-589.

Krimpenfort P, Rademakers A, Eyestone W, van der Schans A, van den Broek S, Kooiman P, et al. 1991. Generation of transgenic dairy cattle using 'in vitro' embryo production. Biotechnology (NY) 9: 844-847.

Kues WA, Niemann H, 2004. The contribution of farm animals to human health. Trends Biotechnol 22: 286-294.

Kuroiwa Y, Kasinathan P, Choi YJ, Naeem R, Tomizuka K, Sullivan EJ, et al. 2002. Cloned transchromosomic calves producing human immunoglobulin. Nat Biotechnol 20: 889-894.

Kuroiwa Y, Kasinathan P, Matsushita H, Sathiyaselan J, Sullivan EJ, Kakitani M, et al. 2004. Sequential targeting of the genes encoding immunoglobulin-mu and prion protein in cattle. Nat Genet 36: 775-780.

Lanza RP, Cibelli JB, Blackwell C, Cristofalo VJ, Francis MK, Baerlocher GM, et al. 2000. Extension of cell life-span and telomere length in animals cloned from senescent somatic cells. Science 288: 665-669.

Lazaris A, Arcidiacono S, Huang Y, Zhou JF, Duguay F, Chretien N, et al. 2002. Spider silk fibers spun from soluble recombinant silk produced in mammalian cells. Science 295: 472-476.

Li L, Shen W, Min L, Dong H, Sun Y, Pan Q, 2006. Human lactoferrin transgenic rabbits produced efficiently using dimethylsulfoxide-sperm-mediated gene transfer. Reprod Fertil Dev 18: 689-695.
Lipinski D, Jura J, Kalak R, Plawski A, Kala M, Szalata M, et al. 2003. Transgenic rabbit producing human growth hormone in milk. J Appl Genet 44: $165-174$.

Maione B, Lavitrano M, Spadafora C, Kiessling AA, 1998. Sperm-mediated gene transfer in mice. Mol Reprod Dev 50: 406-409.

Martin GR, 1981. Isolation of a pluripotent cell line from early mouse embryos cultured in medium condiyioned by teratocarcinoma stem cells. Proc Natl Acad Sci USA 78: 7634-7638.

Marx J, 2003. Medicine. Building better mouse models for studying cancer. Science 299: 1972-1975.

Massoud M, Attal J, Thepot D, Pointu H, Stinnakre MG, Theron MC, et al. 1996. The deleterious effects of human erythropoietin gene driven by the rabbit whey acidic protein gene promoter in transgenic rabbits. Reprod Nutr Dev 36: 555-563.

McCreath KJ, Howcroft J, Campbell KH, Colman A, Schnieke AE, Kind AJ, 2000. Production of gene-targeted sheep by nuclear transfer from cultured somatic cells. Nature 405: 1066-1069.

McKee C, Gibson A, Dalrymple M, Emslie L, Garner I, Cottingham I, 1998. Production of biologically active salmon calcitonin in the milk of transgenic rabbits. Nat Biotechnol 16: 647-651.

McPherron AC, Lawler AM, Lee SJ, 1997. Regulation of skeletal muscle mass in mice by a new TGF-beta superfamily member. Nature 387: 83-90.

McPherron AC, Lee SJ, 1997. Double muscling in cattle due to mutations in the myostatin gene. Proc Natl Acad Sci USA 94: 12457-12461.

Melo EO, Sousa RV, Iguma LT, Franco MM, Rech EL, Rumpf R, 2005. Isolation of transfected fibroblast clones for use in nuclear transfer and transgene detection in cattle embryos. Genet Mol Res 4: 812-821.

Michalak E, Lipinski D, Slomski R, 2006. Loop formation by the transgene WAP: $6 \times$ HishGH in transgenic rabbit fibroblast, revealed by fluorescence in situ hybridization to nuclear halos. J Appl Genet 47: 247-249.

Miller HI, 2002. As biotech turns 20. Nat Rev Drug Discov 1: 1007-1008.

Mogford JE, Liu WR, Reid R, Chiu CP, Said H, Chen SJ, et al. 2006. Adenoviral human telomerase reverse transcriptase dramatically improves ischemic wound healing without detrimental immune response in an aged rabbit model. Hum Gene Ther 17: 651-660.

Muller M, Brenig B, Winnacker EL, Brem G, 1992. Transgenic pigs carrying cDNA copies encoding the murine Mx 1 protein which confers resistance to influenza virus infection. Gene 121: 263-270.

Nagano M, Brinster CJ, Orwig KE, Ryu BY, Avarbock MR, Brinster RL, 2001. Transgenic mice produced by retroviral transduction of male germ-line stem cells. Proc Natl Acad Sci USA 98: 13090-13095.

Nibbering PH, Ravensbergen E, Welling MM, van Berkel LA, van Berkel PH, Pauwels EK, Nuijens JH, 2001. Human lactoferrin and peptides 
derived from its $\mathrm{N}$ terminus are highly effective against infections with antibiotic-resistant bacteria. Infect Immun 69: 1469-1476.

Niemann H, Halter R, Carnwath JW, Herrmann D, Lemme E, Paul D, 1999. Expression of human blood clotting factor VIII in the mammary gland of transgenic sheep. Transgenic Res 8: 237-247.

Noble MS, Rodriguez-Zas S, Cook JB, Bleck GT, Hurley WL, Wheeler MB, 2002. Lactational performance of first-parity transgenic gilts expressing bovine alpha-lactalbumin in their milk. J Anim Sci 80; 1090-1096.

Nottle MB, Haskard KA, Verma PJ, Du ZT, Grupen CG, McIlfatrick SM, et al. 2001. Effect of DNA concentration on transgenesis rates in mice and pigs. Transgenic Res 10: 523-531.

Nuijens JH, van Berkel PH, Geerts ME, Hartevelt PP, de Boer HA, van Veen HA, Pieper FR, 1997. Characterization of recombinant human lactoferrin secreted in milk of transgenic mice. J Biol Chem 272: 8802-8807.

Oliveira RR, Carvalho DM, Lisauskas S, Mello E, Vianna GR, Dode MA, et al. 2005. Effectiveness of liposomes to transfect livestock fibroblasts. Genet Mol Res 4: 185-196.

Paleyanda RK, Velander WH, Lee TK, Scandella DH, Gwazdauskas FC, Knight JW, 1997. Transgenic pigs produce functional human factor VIII in milk. Nat Biotechnol 15: 971-975.

Palmiter RD, Brinster RL, Hammer RE, Trumbauer ME, Rosenfeld MG, Birnberg NC, Evans RM, 1982. Dramatic growth of mice that develop from eggs microinjected with metallothionein-growth hormone fusion genes. Nature 300: 611-615.

Paradis K, Langford G, Long Z, Heneine W, Sandstrom P, Switzer WM, et al. 1999. Search for cross-species transmission of porcine endogenous retrovirus in patients treated with living pig tissue. The XEN 111 Study Group. Science 285: 1236-1241.

Patience C, Patton GS, Takeuchi Y, Weiss RA, McClure MO, Rydberg L, Breimer ME, 1998. No evidence of pig DNA or retroviral infection in patients with short-term extracorporeal connection to pig kidneys. Lancet 352: 699-701.

Patience C, Takeuchi Y, Weiss RA, 1997. Infection of human cells by an endogenous retrovirus of pigs. Nat Med 3: 282-286.

Petters RM, Alexander CA, Wells KD, Collins EB, Sommer JR, Blanton MR, et al. 1997. Genetically engineered large animal model for studying cone photoreceptor survival and degeneration in retinitis pigmentosa. Nat Biotechnol 15: 965-970.

Phelps CJ, Koike C, Vaught TD, Boone J, Wells KD, Chen SH, et al. 2003. Production of alpha 1,3-galactosyltransferase-deficient pigs. Science 299: 411-414.

Polejaeva IA, Campbell KH, 2000. New advances in somatic cell nuclear transfer: application in transgenesis. Theriogenology 53: 117-126.
Powell BC, Walker SK, Bawden CS, Sivaprasad AV, Rogers GE, 1994. Transgenic sheep and wool growth: possibilities and current status. Reprod Fertil Dev 6: 615-623.

Pursel VG, Pinkert CA, Miller KF, Bolt DJ, Campbell RG, Palmiter RD, 1989. Genetic engineering of livestock. Science 244: 1281-1288.

Rieth A, Pothier F, Sirard MA, 2000. Electroporation of bovine spermatozoa to carry DNA containing highly repetitive sequences into oocytes and detection of homologous recombination events. Molecular Reproduction and Development 57: 338-345.

Robertson E, Bradley A, Kuehn M, Evans M, 1986. Germ-line transmission of genes introduced into cultured pluripotential cells by retroviral vector. Nature 323: 445-448.

Rudolph KL, Millard M, Bosenberg MW, DePinho RA, 2001. Telomere dysfunction and evolution of intestinal carcinoma in mice and humans. Nat Genet 28: 155-159.

Rudolph NS, 1999. Biopharmaceutical production in transgenic livestock. Trends Biotechnol 17: 367-374.

Saito S, Sawai K, Ugai H, Moriyasu S, Minamihashi A, Yamamoto Y, et al. 2003. Generation of cloned calves and transgenic chimeric embryos from bovine embryonic stem-like cells. Biochem Biophys Res Commun 309: 104-113.

Schnieke AE, Kind AJ, Ritchie WA, Mycock K, Scott AR, Ritchie M, Wilmut I, et al. 1997. Human factor IX transgenic sheep produced by transfer of nuclei from transfected fetal fibroblasts. Science 278: 2130-2133.

Seidel GE, Jr., 1993. Resource requirements for transgenic livestock research. J Anim Sci 71: 26-33.

Shiels PG, Kind AJ, Campbell KH, Waddington D, Wilmut I, Colman A, Schnieke AE, 1999. Analysis of telomere lengths in cloned sheep. Nature 399: 316-317.

Shim H, Gutierrez-Adan A, Chen LR, BonDurant RH, Behboodi E, Anderson GB, 1997. Isolation of pluripotent stem cells from cultured porcine primordial germ cells. Biol Reprod 57: 1089-1095.

Sikes ML, O’Malley BW, Jr., Finegold MJ, Ledley FD, 1994. In vivo gene transfer into rabbit thyroid follicular cells by direct DNA injection. Hum Gene Ther 5: 837-844.

Soukka T, Tenovuo J, Lenander-Lumikari M, 1992. Fungicidal effect of human lactoferrin against Candida albicans. FEMS Microbiol Lett 69: 223-228.

Souza T, MacDougall C, Campbell BK, McNeilly AS, Baird DT, 2001. The Booroola (FecB) phenotype is associated with a mutation in the bone morphogenetic receptor type $1 \mathrm{~B}$ (BMPR1B) gene. J Endocrinol 169: R1-6.

Stacey A, Schnieke A, Kerr M, Scott A, McKee C, Cottingham I, et al. 1995. Lactation is disrupted by alpha-lactalbumin deficiency and can be restored by 
human alpha-lactalbumin gene replacement in mice. Proc Natl Acad Sci USA 92: 2835-2839.

Stinnakre MG, Vilotte JL, Soulier S, Mercier JC, 1994. Creation and phenotypic analysis of alpha-lactalbumin-deficient mice. Proc Natl Acad USA 91: 6544-6548.

Suda O, Smith LA, d'Uscio LV, Peterson TE, Katusic ZS, 2005. In vivo expression of recombinant vascular endothelial growth factor in rabbit carotid artery increases production of superoxide anion. Arterioscler Thromb Vasc Biol 25: 506-511.

Sullivan EJ, Kasinathan S, Kasinathan P, Robl JM, Collas P, 2004. Cloned calves from chromatin remodeled in vitro. Biol Reprod 70: 146-153.

Thomas KR, Capecchi MR, 1987. Site-directed mutagenesis by gene targeting in mouse embryo-derived stem cells. Cell 51: 503-512.

Van Berkel PH, Welling MM, Geerts M, van Veen HA, Ravensbergen B, Salaheddine M, et al. 2002. Large scale production of recombinant human lactoferrin in the milk of transgenic cows. Nat Biotechnol 20: 484-487.

Van Doorn MB, Burggraaf J, van Dam T, Eerenberg A, Levi M, Hack CE, et al. 2005. A phase I study of recombinant human $\mathrm{C} 1$ inhibitor in asymptomatic patients with hereditary angioedema. J Allergy Clin Immunol 116: 876-883.

Velander WH, Johnson JL, Page RL, Russell CG, Subramanian A, Wilkins TD, et al. 1992. High-level expression of a heterologous protein in the milk of transgenic swine using the cDNA encoding human protein C. Proc Natl Acad Sci USA 89: 12003-12007.

Wakayama T, Shinkai Y, Tamashiro KL, Niida H, Blanchard DC, Blanchard RJ, et al. 2000. Cloning of mice to six generations. Nature 407: 318-319.

Wall RJ, Kerr DE, Bondioli KR, 1997. Transgenic dairy cattle: genetic engineering on a large scale. J Dairy Sci 80: 2213-2224.

Wall RJ, Powell AM, Paape MJ, Kerr DE, Bannerman DD, Pursel VG, 2005. Genetically enhanced cows resist intramammary Staphylococcus aureus infection. Nat Biotechnol 23: 445-451.

Waterston RH, Lindblad-Toh K, Birney E, Rogers J, Abril JF, Agarwal P, et al. 2002. Initial sequencing and comparative analysis of the mouse genome. Nature 420: 520-562.
Weissmann C, Enari M, Klohn PC, Rossi D, Flechsing E, 2002. Transmission of prions. Proc Natl Acad Sci USA 99: 16378-16383.

Wheeler MB, 2003. Production of transgenic livestock: promise fulfilled. J Anim Sci 81: 32-37.

Willadsen SM, 1986. Nuclear transplantation in sheep embryos. Nature 320: 63-65.

Williams RS, Johnston SA, Riedy M, DeVit MJ, McElligott SG, Sanford JC, 1991. Introduction of foreign genes into tissues of living mice by DNA-coated microprojectiles. Proc Natl Acad Sci USA 88: 2726-2730.

Wilmut I, Schnieke AE, McWhir J, Kind AJ, Campbell KH, 1997. Viable offspring derived from fetal and adult mammalian cells. Nature 385: $810-813$.

Wobus AM, Boheler KR, 2005. Embryonic stem cells: prospects for developmental biology and cell therapy. Physiol Rev 85: 635-678.

Wright G, Carver A, Cottom D, Reeves D, Scot A, Simons P, et al. 1991. High level expression of active human alpha-1-antitrypsin in the milk of transgenic sheep. Biotechnology (NY) 9: 830-834.

Zaidi A, Schmoeckel M, Bhatti F, Waterworth P, Tolan M, Cozzi E, et al. 1998. Life-supporting pig-to-primate renal xenotransplantation using genetically modified donors. Transplantation 65: 1584-1590.

Zawada WM, Cibelli JB, Choi PK, Clarkson ED, Golueke PJ, Witta SE, et al. 1998. Somatic cell cloned transgenic bovine neurons for transplantation in parkinsonian rats. Nat Med 4: 569-574.

Zbikowska HM, Soukhareva N, Behnam R, Chang R, Drews R, Lubon H, et al. 2002a. The use of the uromodulin promoter to target production of recombinant proteins into urine of transgenic animals. Transgenic Res 11: 425-435.

Zbikowska HM, Soukhareva N, Behnam R, Lubon H, Hammond D, Soukharev S, 2002b. Uromodulin promoter directs high-level expression of biologically active human alpha1- antitrypsin into mouse urine. Biochem J 365: 7-11. 